\section{Israel introduces organ} swap scheme

Israel's Health Ministry has announced an unusual program aimed at increasing the number of kidney transplants from live donors. The program, believed to be the first of its kind in the world, is based on cross-donation: it will create a pool of people who want to give a kidney to save a relative's life, but whose tissue type is not compatible with the would-be recipient. Instead, a donor will be sought from another family and in return, the altruistic relative will donate a kidney to somebody of the donor's choosing, compatibility permitting.

The two transplants will be performed simultaneously, to make sure that one side does not change its mind at the last moment while the other proceeds with the transplantation.

The complicated kidney swap scheme is being tried because of a dire shortage of organs from cadavers in Israel. Only 50 percent of kidney transplants are from cadavers, while in some developed countries this number is as high as 90 percent. According to the Israel Medical Association (IMA), only one percent of Israelis carry an organ donation card, compared with 15 percent of Americans.

This may be due to Judaism's tough stand on cadaver organ transplants; although allowed in principle, there is a prevailing fear that a potential donor may be declared dead prematurely. The result is an ongoing battle between doctors and rabbis as to who has the right to pronounce a person dead and when.

There are currently around 900 Israelis on the waiting list for a kidney transplant, with 200 patients added every year, according to Tamar Ashkenazi, Israel's national transplant coordinator. "It's impossible to foresee how many transplants, if any, are likely to be added by the new program, but ten a year would be a good number," Ashkenazi says. She says that around a dozen families signed up immediately when the program was announced.

But the new scheme also has its critics. IMA's President Yoram Blachar warns that cross-donation may be a slippery slope towards a trade in organs, which is banned in most Western nations. Furthermore, he argues that the program diverts attention from the real issue that should urgently be addressed instead, namely, the shortage of organs from cadavers. Luba Vikhanski, Tel Aviv

\title{
Fight to develop drug addiction therapy
}

A new phase in the acrimonious legal struggle over the development of an anti-addiction drug (ibogaine) began last month when the trial was moved to Florida. Because the trial centers on work carried out at the University of Miami, the suit was dismissed for jurisdic-
tional reasons by courts in New UNAVAILABLE York. Now the Miami judicial system is faced with resolving a case that involves the US Food and Drug Administration (FDA), a senior neuroscientist, a Caribbean drug treatment center, the National Institute for Drug Addiction (NIDA) and the ibogaine use-patent holder, Howard Lotsof.

Lotsof discovered ibogaine's anti-addictive potential thirty years ago when he experimented with the drug as a 19 year old heroin addict. Since that time, he claims to have spent 17 years and \$1 million trying to bring the drug to market as an addiction therapy (Endabuse) through his Staten Island company, NDA International Inc.

Ibogaine is purported to cure heroin and cocaine addiction by removing the physiological and psychological characteristics of dependency without inducing withdrawal symptoms (Nature Med. 1; 288 , 1995). Remarkably, it is claimed that ibogaine achieves this effect in one dose
Legal proceedings began last April when Deborah UNAVAILABLE FOR Mash, Professor of Neurology at the University of Miami and principal investigator in FDA-approved Phase I trials of the drug, filed a motion accusing Lotsof of fraud. Mash alleges that Lotsof covertly took out a patent on an ibogaine metabolite (Noribogaine Plus), that is more effective than the parent compound-a discovery made by Mash but not attributed to her. Mash is demanding that the patent, issued to Lotsof in January 1997, be canceled and requests compensation. Her petition makes a clear distinction between her reputation as a "world renowned scientist in the field of neurology" and Lotsof's lack of scientific background.

Lotsof counter-sued in August, claiming that Mash and the University of Miami violated their 1992 contract to perform the Phase I study. He further alleges that Mash is currently infringing his company's intellectual property rights for her own commercial benefit at a drug treat- ment facility on the Caribbean island of St. Kitts.

Mash agrees that early clinical studies of the drug were suspended and says it was for good reason: In 1993, a woman in the Netherlands died, reportedly due to an ibogaine overdose, while being treated in a hotel room. Mash says she had an ethical responsibility to stop human testing while the affair was investigated. Furthermore, she says that NDA International was not providing financial support for the study.

Despite these problems, Mash and Lotsof were still on good terms. After the Dutch death, Mash helped Lotsof set up a program in Panama, where subjects were to be treated in medical surroundings and monitored at the University of Miami. But by the time NIDA held an ibogaine consensus meeting in 1995, their relationship had deteriorated beyond repair. The NIDA advisory panel ruled against further studies of the drug-some believe for reasons of toxicity and others say on political grounds-and the ibogaine story looked to have come to a close.

Not so. According to Mash, in 1996 a group of private individuals who had enough respect for her as a scientist" funded a treatment center called Healing Visions in St Kitts. Here she has used ibogaine to treat private customers-one Chicago lawyer is said to have paid $\$ 12,000$ for treatmentand all outside the reaches of US patent law.

Despite criticism that she has chosen an unconventional route to proceed with her research, Mash insists that working in St Kitts is the only way she can collect patient data. She is dismissive of Lotsof's patent rights which, she says, "won't last for ever" and plans to file for clinical trial approval in the US once she has sufficient preliminary evidence that ibogaine is safe and effective. She freely admits that she is staking her scientific career on the drug.

Lotsof is equally determined to see the project through, since he too has devoted his life to the pursuit of ibogaine as a cure for dependency. He has hired a new lawyer in Miami and is awaiting a trial start date.

KaREN BIRMINGHAM, New York 